\title{
HER3 genomic gain and sensitivity to gefitinib in advanced non-small-cell lung cancer patients
}

\author{
F Cappuzzo ${ }^{1,2}$, L Toschi ${ }^{1,2}$, I Domenichini ${ }^{3}$, S Bartolini ${ }^{2}$, GL Ceresoli ${ }^{4}$, E Rossi $^{3}$, V Ludovini $^{5}$, A Cancellieri $^{2}$, \\ E Magrini ${ }^{2}$, L Bemis', WA Franklin', L Crino ${ }^{2}$, PA Bunn Jr', FR Hirsch' and M Varella-Garcia ${ }^{*}, 1$ \\ 'Department of Medicine/Medical Oncology and Pathology, University of Colorado Cancer Center, Campus Box 81 I 7; PO Box 65 II, Aurora, CO 80045, \\ USA; ${ }^{2}$ Department of Medical Oncology, Bellaria-Maggiore Hospital, Bologna, Italy; ${ }^{3}$ CINECA-Interuniversity Consortium, Bologna, Italy; ${ }^{4}$ Department of \\ Medical Oncology, Scientific Institute University Hospital San Raffaele, Milano, Italy; ${ }^{5}$ Department of Medical Oncology, Policlinico Monteluce, Perugia, \\ Italy
}

In non-small-cell lung cancer (NSCLC), sensitivity to tyrosine kinase inhibitors (TKIs) is associated with activating mutations and genomic gain of the epidermal growth factor receptor (EGFR). Preclinical data suggested that HER3 overexpression increases sensitivity to TKIs. A total of 82 NSCLC patients treated with gefitinib (250 mg), and previously evaluated for EGFR and HER2 status by fluorescence in situ hybridisation (FISH) and DNA sequencing, and for Phospho-Akt status by immunohistochemistry, were investigated for HER3 genomic gain by FISH. Patients with high polysomy and gene amplification were considered as HER3 FISH positive $(+)$. HER3 FISH + pattern was significantly associated with female gender $(P=0.02)$ and never smoking history $(P=0.02)$. Patients with HER3 + tumours (26.8\%) had a significantly longer time to progression (3.7 vs 2.7, $P=0.04)$ than patients with HER3tumours, but not a significantly better response rate or survival. Patients with EGFR + /HER3 + tumours had higher objective response rate (36.4 vs 9.9\%, $P=0.03$ ) and time to progression (7.7 vs 2.7 months, $P=0.03$ ) than patients with $E G F R-$ and/or HER3 - tumours, but no significantly longer survival. No difference in response was observed according to HER3 status in patients with EGFR + tumours. Patients with HER2 + /HER3 + tumours had similar outcome as patients with HER2- and/or HER3tumours. Significantly different clinical end points were not observed between patients with HER3 +/P-Akt + and HER3- and/or P-Akt - tumours. Genomic gain for HER3 is not a marker for response or resistance to TKI therapy in advanced NSCLC patients. British Journal of Cancer (2005) 93, I334-1340. doi:I0.1038/sj.bjc.6602865 www.bjcancer.com

Published online 15 November 2005

(c) 2005 Cancer Research UK

Keywords: HER3; EGFR; tyrosine kinase inhibitor; gefitinib; non-small-cell lung cancer

Non-small-cell lung cancer (NSCLC) has been the leading cause of cancer death in the world (Greenlee et al, 2001). Platinum-based chemotherapy is the standard of care for advanced NSCLC, but even with newly developed chemotherapy strategies the median survival rarely exceeds 9 months and the fraction of patients alive after 1 year is approximately 30\% (Non-small cell Lung Cancer Collaborative Group, 1995; Kelly et al, 2001; Schiller et al, 2002). In recent years, several new agents able to interfere with critical oncogenic mechanisms have been evaluated in clinical trials. Among them, the most promising classes of compounds are those targeting tyrosine kinases. The epidermal growth factor receptor (EGFR), including EGFR (Erb-B1), HER2/neu (Erb-B2), HER3 (Erb-B3) and HER4 (Erb-B4), is a family of receptor tyrosine kinases representing ideal therapeutic targets because they play a critical role in cancer proliferation and survival (Woodburn, 1999).

\footnotetext{
*Correspondence: Dr M Varella-Garcia;

E-mail: Marileila.Garcia@uchsc.edu

Institutions to which the work should be attributed: University of Colorado Health Sciences Center and University of Colorado Cancer Center, Aurora, CO, USA, and Bellaria-Maggiore Hospital, Bologna, Italy. Received 20 July 2005; revised 14 October 2005; accepted 17 October 2005; published online 15 November 2005
}

A number of different ligands, including EGF, transforming growth factor alpha and neuregulins, activate these receptors by binding to the extracellular domain and inducing the formation of receptor homodimers or heterodimers followed by internalisation of the receptor/ligand complex and autophosphorylation. As a result, the tyrosine kinase signal transduction pathways are activated (Carpenter and Cohen, 1979; Yarden and Ullrich, 1988).

During the last decade, several new agents interfering with the EGFR family activity have been developed (Ciardiello et al, 2003). Among the most promising of these new drugs are gefitinib (ZD 1839, Iressa ${ }^{\circledR}$, AstraZeneca, UK) and erlotinib (OSI 774, Tarceva ${ }^{\circledR}$, Genentech, USA). Both are orally active, selective EGFR tyrosine kinase inhibitors (EGFR-TKI) that demonstrated anti-tumoural activity in approximately $10 \%$ of unselected NSCLC (Fukuoka et al, 2003; Kris et al, 2003), with a survival benefit when compared with placebo that was statistically significant only in the case of erlotinib (Shepherd et al, 2005; Thatcher et al, 2005). Molecular mechanisms underlying TKI sensitivity have been recently discovered. Patients with specific EGFR gene mutations and/or genomic gain demonstrated to be particularly sensitive to the inhibitory effects of TKIs (Lynch et al, 2004; Paez et al, 2004; Pao et al, 2004; Cappuzzo et al, 2005a; Hirsch et al, 2005; Tsao et al, 2005), although a favourable prognostic role of EGFR gene mutations cannot be ruled out (Bell et al, 2005; Eberhard et al, 
2005). It is also known that EGFR mutations activated the antiapoptotic protein Akt (Sordella et al, 2004), and that patients whose tumours have activated Akt are more sensitive to TKIs than patient whose tumours are phospho-AKT negative (Cappuzzo et al, 2004).

Among the four members of the EGFR family, HER3 is unique because of its catalytically deficient kinase domain (Guy et al, 1994) and its high propensity to self-associate in the absence of ligand (Landgraf and Eisenberg, 2000), and the ability to assume a locked conformation, using an intramolecular tether (Cho and Leahy, 2002). HER3 signalling relies on heterodimerisation with other EGFR family member, preferentially HER2 (Sliwkowski et al, 1994). Simultaneous overexpression of both HER2 and HER3 was found in several cancers (Naidu et al, 1998; Krahn et al, 2001), and increased drug resistance in many HER2-overexpressing cancers depends on increased levels of HER3 or EGFR (Chen et al, 2000).

Because of the rich crosstalk among the EGFR family members, the TKI sensitivity is not only directly dependent on the presence of EGFR but also largely influenced by other family members, particularly HER2. In previous studies, we observed that HER2 gene gain (Cappuzzo et al, 2005b) but not HER2 protein expression (Cappuzzo et al, 2003) was related to gefitinib sensitivity, and EGFR + patients with increased HER2 gene copy number had a significantly higher response rate, time to progression and survival. Moreover, preclinical data indicated that gefitinib inhibits cell proliferation by sequestration of HER2 and HER3 receptors in an inactive heterodimer configuration with EGFR (Anido et al, 2003).

In previous studies, we also reported that activation of the antiapoptotic protein Akt was significantly associated with gefitinib sensitivity (Cappuzzo et al, 2004), with a significant improvement in survival only when Akt activation was sustained by an EGFR-dependent mechanism (Cappuzzo et al, 2005a). Moreover, it is known that EGFR-mediated activation of Akt requires the activation of phosphatidylinositol 3 kinase (PI3K), and this can occur via dimerisation of EGFR with HER3, which is able to directly couple to PI3K (Fedi et al, 1994). Finally, a recent study showed that HER3 is used to couple EGFR to the PI3K/Akt pathway in gefitinib-sensitive NSCLC cell lines harboring wild-type and mutant EGFR (Engelman et al, 2005). Signalling through HER3 is fundamentally different from the other members of the HER family since HER3 has no tyrosine kinase activity but directly activates PI3K. Based on these data, we hypothesised that HER3 gene copy number could be relevant for gefitinib sensitivity, and increased copy number the HER3 gene could enhance gefitinib sensitivity in EGFR + patients. This hypothesis was tested through the investigation of the HER3 status by fluorescence in situ hybridisation (FISH) in a cohort of NSCLC patients treated with gefitinib and previously evaluated for phospho-Akt (P-Akt) expression by immunohistochemistry (IHC), EGFR and HER2 status by FISH and DNA sequencing (Cappuzzo et al, 2004, $2005 a, b)$

\section{METHODS}

\section{Patient population}

NSCLC patients included in this study were treated at three Italian institutions: Bellaria-Maggiore Hospital (Bologna), Scientific Institute University Hospital San Raffaele (Milano) and Policlinico Monteluce (Perugia). The cohort included 82 patients with advanced NSCLC accrued onto the AKT prospective clinical trial (Cappuzzo et al, 2004) or consecutively accrued from the Expanded Access Study (EAS) of gefitinib that followed the Akt trial. Eligibility for both studies included histologically confirmed NSCLC with measurable, locally advanced or metastatic disease, progressing or relapsing after chemotherapy, or medical contra- indications for chemotherapy. Patients were classified as never smoker, former smoker (quit smoking more than 6 months before starting gefitinib therapy) or current smoker (quit smoking less than 6 months before starting gefitinib therapy or active smokers). The AKT study was approved by the Bellaria Hospital institutional ethical review board and written informed consent was obtained from each patient before enrollment. In the subgroup of EAS patients, the IRB approval was obtained according to Good Clinical Practice, and a specific written informed consent was obtained from each patient (EAS consent form, Italian version).

Patients received gefitinib $\left(250 \mathrm{mg} \mathrm{day}^{-1}\right)$ and were evaluated for response after 2 months according to the RECIST criteria (Therasse et al, 2000). Tumour response was assessed by computer tomography scan, with a confirmatory evaluation repeated in patients with complete response, partial response, and stable disease at least 4 weeks after the initial determination of response. Outcome in these patients was previously reported and associated with EGFR (Cappuzzo et al, 2005a) and HER2 status (Cappuzzo et al, 2005b). Among the patients'characteristics, female gender and never smoking status were significantly associated with better response; and female gender, adenocarcinoma and bronchioloalveolar histology and performance status $0-1$ were significantly associated with longer survival.

No clinical or biological characteristics were used for patient selection for this study; the single criterion considered was the availability of tumour tissue and availability of information on P-Akt, EGFR and HER2 FISH status.

\section{Tissue preparation, FISH and IHC analyses}

Sections from paraffin-embedded tissue blocks containing representative malignant cells obtained at time of diagnosis were used for this analysis. Histopathological classification was determined on hematoxylin-eosin (HE)-stained sections based on the World Health Organization criteria (Travis et al, 1999). The HE-stained slide was also used as a reference for selection of tumour foci to be analysed in the FISH assay. The HER3 FISH probe was prepared from the BAC clone RP11-603J24; acquired from BACPAC Resource Center (Children's Hospital Oakland Research Institute, Oakland, CA, USA). Single colony culture was used for amplification of the selected DNA sequences and the extracted BAC DNA was tested for the presence of HER3 sequences with PCR primers as follows: forward HER3 primer: 5'- GACATCAAGCA TAATCGGCC-3'; reverse HER3 primer: 5'- CAGGACAAGCACT GACCAG-3' and mapped by FISH to normal human karyotype. HER3 DNA was labeled by nick translation reaction with SpectrumRed-conjugated dUTP (Nick Translation Kit and reagents from Vysis/Abbott Laboratories) according to the manufacturer's instructions. The CEP12 (D12Z3) SpectrumGreen probe (Vysis/ Abbott Lab, Downers Grove, IL, USA) was used as a control for chromosome 12 aneusomy.

Dual-target, dual-color FISH assays were performed as previously described (Cappuzzo et al, 2005a), using a combination of $120 \mathrm{ng}$ HER3-SR, $5 \mathrm{ng}$ CEP12-SG per hybridisation area. Briefly, sections were deparaffinised in CitriSolv (Fisher Scientific, Pittsburgh, PA, USA), dehydrated in $100 \%$ ethanol, incubated in $2 \times$ saline sodium citrate buffer $(2 \times \mathrm{SSC} ; \mathrm{pH} 7.0)$ at $75^{\circ} \mathrm{C}$ for $15-$ $25 \mathrm{~min}$, and digested with proteinase $\mathrm{K}\left(0.25 \mathrm{mg} \mathrm{ml}^{-1}\right.$ in $2 \times \mathrm{SSC}$; $\mathrm{pH} 7.0$ ) at $37^{\circ} \mathrm{C}$ for $15-25 \mathrm{~min}$. After dehydration in an ethanol series, the probe set was applied and slides were incubated at $80^{\circ} \mathrm{C}$ for 8-10 min for codenaturation of chromosomal and probe DNA, Hybridisation was allowed to occur at $37^{\circ} \mathrm{C}$ for approximately $40 \mathrm{~h}$ and posthybridisation washes were performed in $1.5 \mathrm{M}$ urea and $0.1 \times \operatorname{SSC}(\mathrm{pH} 7.0-7.5)$ at $45^{\circ} \mathrm{C}$ for $30 \mathrm{~min}$ and in $2 \times$ SSC for $2 \mathrm{~min}$ at room temperature. After dehydration in graded ethanol series, $4^{\prime} 6$-diamidino-2-phenylindole $\left(0.30 \mathrm{mg} \mathrm{ml}^{-1}\right.$ in Vectashield mounting medium; Vector Laboratories, Burlingame, CA, USA) was applied to the samples for chromatin counterstaining. Copy 
numbers of the HER3 gene and chromosome 12 centromere probes were assessed and recorded independently in at least 100 nonoverlapping nuclei from distinct tumour foci. Analysis was performed independently by two observers (LT, MVG) blinded to the patients' clinical characteristics and other receptors' status. According to the frequency of tumour cells with specific number of copies of the HER3 gene and chromosome 12 centromere, patients were classified into two strata: HER3 FISH negative (FISH-), with no or low genomic gain ( $\leqslant 4$ copies of the gene in $>40 \%$ of cells) and HER3 FISH positive (FISH + ), with high level of polysomy $(\geqslant 4$ copies of the gene in $\geqslant 40 \%$ of cells) or gene amplification (presence of tight gene clusters, a ratio gene/chromosome per cell $\geqslant 2$, or $\geqslant 15$ copies of the gene in $\geqslant 10 \%$ of analysed cells).

\section{Statistical analysis}

Differences between the FISH groups were compared by Fisher's exact test or $\chi^{2}$ test for qualitative variables and Student's by $t$-test. Normality of the distribution was assessed by KolmogorovSmirnov test. Time to progression (TTP), overall survival (OS) and the $95 \%$ confidence intervals were evaluated by the Kaplan-Meier method (Kaplan and Meier, 1985), comparing the FISH groups by log-rank test.

\section{RESULTS}

\section{HER3 FISH}

Among 82 NSCLC patients, no or low genomic gain for the HER3 gene (HER3-) was found in $73.2 \%$ of cases, whereas high polysomy and gene amplification $($ HER3 + ) was detected in $26.8 \%$ (Figure 1). Among clinical characteristics (Table 1), HER3 + was significantly associated with female gender
Table I Patient characteristics and HER3 FISH status in NSCLC

\begin{tabular}{|c|c|c|c|c|}
\hline \multirow[b]{2}{*}{ Characteristics } & \multicolumn{4}{|c|}{ HER3 FISH status } \\
\hline & $\begin{array}{c}\text { Total } \\
\mathbf{N}=\mathbf{8 2} \\
\text { No (\%) }\end{array}$ & $\begin{array}{c}\text { Positive } \\
\mathbf{N}=\mathbf{2 2} \\
\text { No. (\%) }\end{array}$ & $\begin{array}{c}\text { Negative } \\
\begin{array}{c}N=60 \\
\text { No (\%) }\end{array}\end{array}$ & $P$ \\
\hline \multicolumn{5}{|l|}{ Sex } \\
\hline Male & 57 (69.5) & II (50.0) & $46(76.7)$ & \\
\hline Female & $25(30.5)$ & II (50.0) & $14(23.3)$ & $0.02 *$ \\
\hline \multicolumn{5}{|l|}{ Age (years) } \\
\hline Median & 61.5 & 59.5 & 62 & \\
\hline$<62$ & $44(53.7)$ & $13(59.1)$ & $31(51.7)$ & 0.55 \\
\hline$\geqslant 62$ & $38(46.3)$ & $9(40.9)$ & $29(48.3)$ & \\
\hline \multicolumn{5}{|l|}{ Histology } \\
\hline Adenocarcinoma $^{a}$ & $43(52.4)$ & $12(54.5)$ & $31(51.7)$ & 0.59 \\
\hline Bronchioloalveolar ${ }^{a}$ & $9(11.0)$ & $3(13.6)$ & $6(10.0)$ & $P\left({ }^{a} v s^{b}\right)$ \\
\hline Squamous cell ${ }^{\mathrm{b}}$ & $23(28.0)$ & $5(22.7)$ & $18(30.0)$ & \\
\hline Large cell ${ }^{\mathrm{b}}$ & I (1.2) & | (4.5) & $0(0)$ & \\
\hline Undifferentiated $^{b}$ & $6(7.3)$ & I (4.5) & $5(8.3)$ & \\
\hline \multicolumn{5}{|l|}{ Performance status } \\
\hline 0 & $43(52.4)$ & $12(54.5)$ & $31(5 \mid .7)$ & 0.7 \\
\hline 1 & $30(36.6)$ & $7(31.8)$ & $23(38.3)$ & $P(0+\mid$ vs 2$)$ \\
\hline 2 & $9(11.0)$ & $3(13.6)$ & $6(10.0)$ & \\
\hline \multicolumn{5}{|l|}{ Smoking status } \\
\hline Never smoker & $10(12.2)$ & $6(27.3)$ & $4(6.7)$ & $0.02 *$ \\
\hline Former smoker & $30(36.6)$ & $6(27.3)$ & $24(40.0)$ & $P$ (Never vs others) \\
\hline Current smoker & $42(52.2)$ & $10(45.5)$ & $32(53.3)$ & \\
\hline
\end{tabular}

*Statistically significant. HER3 FISH- corresponds to no or low gain in copy numbers for the HER3 gene and HER3 FISH+ corresponds to high levels of gain for HER3 gene copy number (high polysomy and gene amplification). ${ }^{\mathrm{a}, \mathrm{b}}$ Grouping for statistics.
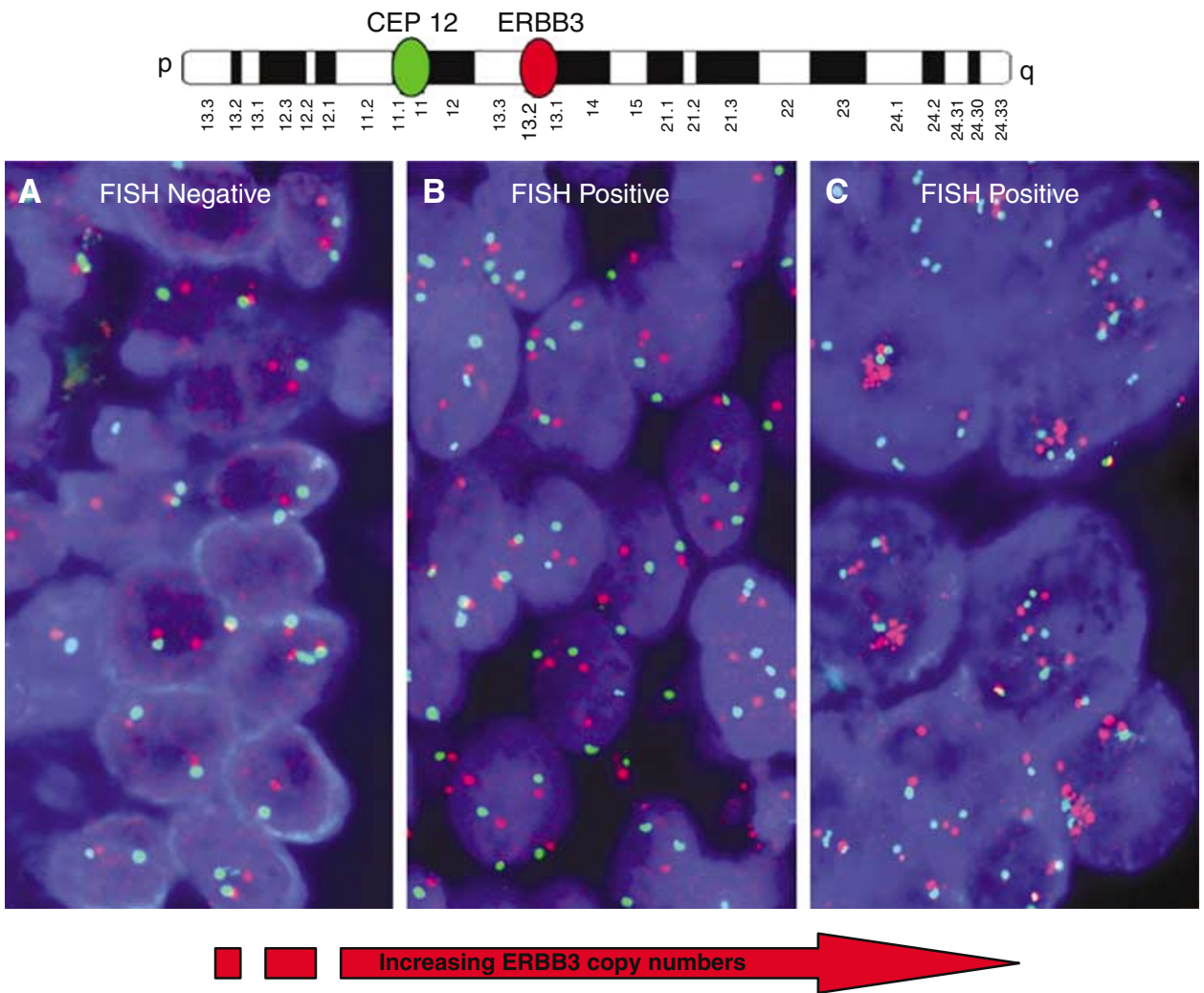

Figure I FISH with the HER3 probe. (A) No genomic gain (pattern: disomy); (B) high gene and chromosome copy numbers and (C) gene amplification. 
$(P=0.02)$ and never smoking history $(P=0.02)$, while no significant association was found with age, histology, stage and performance status.

Table 2 shows the association between HER3 FISH patterns and response to treatment, TTP and OS after treatment. No significant difference in overall response (OR, including complete and partial response), disease control rate (DCR, including OR and stable disease), TTP, and OS was observed between the two HER3 FISH strata. In the HER 3 + group, OR was $18.2 \%$ and DCR was $45.5 \%$, which was not significantly better than observed in the HER3cohort $(\mathrm{OR}=11.7 \%, P=0.47 ; \mathrm{DCR}=35 \%, P=0.38)$. HER3 + patients had a significantly longer TTP (3.7 vs 2.7 months, $P=0.044)$, with no difference in terms of survival (10.1 vs 11.3 months, $P=0.75$, Figure 2).

\section{EGFR, HER2, P-AKT and HER3 association}

Efficacy analysis Epidermal growth factor receptor and HER2 gene copy number by FISH, mutations in the tyrosine kinase domain of the EGFR and HER2 genes by DNA sequencing and presence of phosphorylated AKT by immunohistochemistry have been previously determined in this cohort (Cappuzzo et al, 2005a, b). Combining those results with the current analysis, it was verified that HER3 gene gain was observed more frequently in patients with EGFR gene gain $(P=0.06)$, and HER2 gene gain $(P=0.055)$, without a significant association with EGFR gene mutations $(P=0.17)$ and Akt phosphorylation $(P=0.47)$ (Table 3$)$.

Table 4 shows the results in terms of OR and DCR in subsets of patient stratified according to EGFR FISH and HER3 status. Compared to patients with tumours negative for EGFR and/or HER3, individuals with tumours positive for both EGFR and HER3 $($ EGFR FISH + /HER3 + ) had a significantly higher OR (36.4 vs $9.9 \%, P=0.037)$ and a significantly longer TTP (7.7 vs 2.7 months, $P=0.032$ ), with a non significant trend toward longer survival (13.8 vs 10.1 months, $P=0.27$, Figure 3 ). Patients with tumours positive for both EGFR and HER3 had similar outcome than patients EGFR FISH + /HER3- $(\mathrm{OR}=36.4$ vs 29.4\%, $P=1.0$; $\mathrm{DCR}=63.6$ vs $58.8 \%, P=1.0$; TTP $=7.7$ vs 9.0 months, $P=0.32$, and $\mathrm{OS}=13.8$ vs 18.7 months, $P=0.85$ ). In this study cohort, 13 patients (7 HER3 - and 6 HER3 + ) had tumours with EGFR gene mutations. No difference was observed among EGFR mutation + patients according to HER3 status and, because of the small

Table 2 Objective response rate, disease control rate, TTP and survival analysis in NSCLC patients treated with gefitinib whose tumours showed no or low gain in copy numbers for the HER3 gene (HER3 FISH-) and high levels of gain for HER3 gene copy number $(\mathrm{HER} 3 \mathrm{FISH}+$ )

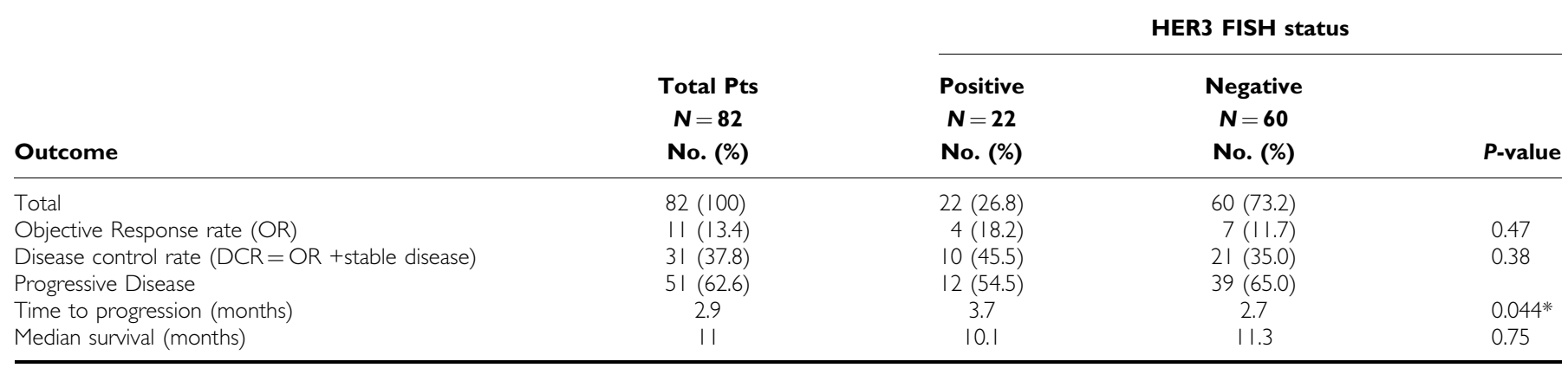

*Statistically significant.
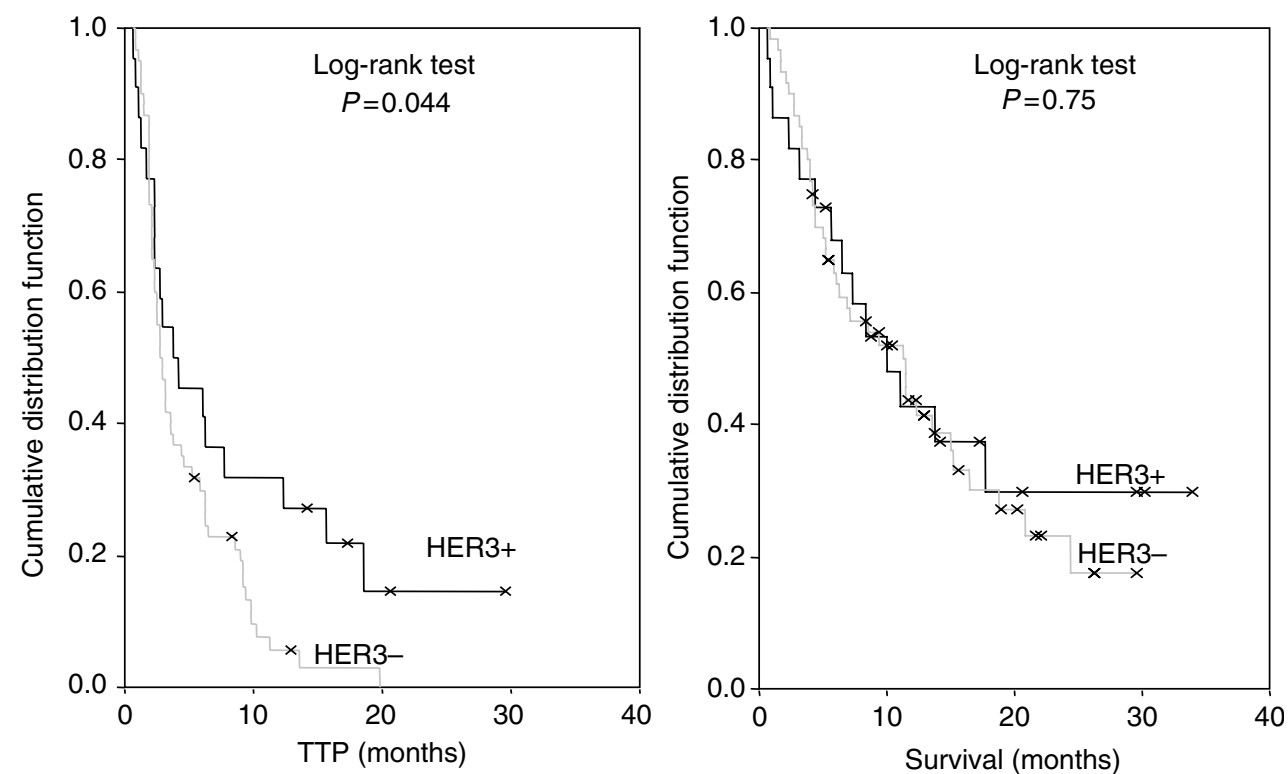

Figure 2 TTP and survival curves for patients with HER3 + and HER3 - tumours. Median TTP and survival were 3.7 and I0.I months in HER3 + and 2.7 and 11.3 months in HER3- $(P=0.044$ and 0.75 , respectively). 
number of patients in each group, outcome was not statistically compared. However, responders were observed in the EGFR mutation $+/$ HER3 + group (three patients) and in the EGFR mutation + /HER3 - group (five patients).

Table 3 Association of HER3 FISH status and EGFR FISH, EGFR mutation, HER2 FISH and P-Akt status

\begin{tabular}{|c|c|c|c|c|}
\hline \multirow[b]{2}{*}{ Markers } & \multirow[b]{2}{*}{$\begin{array}{c}\text { Total Pts } \\
\mathbf{N}=\mathbf{8 2} \\
\text { No. (\%) }\end{array}$} & \multicolumn{3}{|c|}{ HER3 FISH status } \\
\hline & & $\begin{array}{c}\text { Positive } \\
N=22 \\
\text { No. (\%) }\end{array}$ & $\begin{array}{c}\text { Negative } \\
N=60 \\
\text { No. (\%) }\end{array}$ & $P$-value \\
\hline EGFR FISH+ $+^{a}$ & 28 & I | (39.3) & $17(60.7)$ & 0.06 \\
\hline EGFR FISH- ${ }^{a}$ & 54 & II (20.4) & $43(79.6)$ & \\
\hline HER2 FISH $+^{b}$ & 21 & $9(42.9)$ & $12(57.1)$ & 0.055 \\
\hline HER2 FISH- ${ }^{b}$ & 61 & $13(21.3)$ & 48 (78.7) & \\
\hline EGFR Mutation+ $+^{a}$ & 13 & $6(46.2)$ & $7(53.8)$ & 0.17 \\
\hline EGFR Mutation- ${ }^{a}$ & 60 & $15(25.0)$ & $45(75.0)$ & \\
\hline P-AKT $+^{a}$ & 52 & $16(30.8)$ & $36(69.2)$ & 0.47 \\
\hline P-AKT- ${ }^{a}$ & 26 & $6(23.1)$ & $20(76.9)$ & \\
\hline
\end{tabular}

${ }^{a}$ According to Cappuzzo et al (2005a). ${ }^{b}$ According to Cappuzzo et al (2005b).
Nine patients had tumours positive for both HER2 and HER3. In this group of individuals, OR (33vs 11\%, $P=0.063$ ), DCR (56 vs $36 \%, P=0.28)$, TTP (7.7 vs 2.9 months, $P=0.1)$ and OS (13.8 vs 10.9 months, $P=0.63$ ) were not significantly different from patients with tumours HER2 - and/or HER3-. Among the nine HER 2 + /HER3 + patients, only three were also EGFR FISH - and they presented no response, the median TTP was 2.3 months, and the median OS was 2.4 months.

Tumours from a total of 16 patients were both HER3 + and P$\mathrm{Akt}+$. In this group of patients, OR (25 vs $11 \%, P=0.22)$, DCR (44 vs $37 \%, P=0.62)$, TTP (3.7 vs 2.9 months, $P=0.20)$ and OS (8.3 vs 11.5 months, $P=0.72$ ) were not significantly different than observed in HER3 - and/or P-Akt- individuals. Importantly, among the eight cases HER3 + /P-Akt + and EGFR FISH-, no objective response was detected, TTP was 2.4 months and median OS was 6.5 months. Conversely, among the eight cases HER3 + /P$\mathrm{Akt}+$ and EGFR FISH + , four patients responded, two had disease stabilisation, and only two progressed.

\section{DISCUSSION}

In the present study, we analysed the HER3 gene status by FISH in a cohort of NSCLC patients treated with gefitinib and observed that increased HER3 gene copy number had a low impact in drug sensitivity. Although TTP was significantly longer in HER3+

Table 4 Outcome of NSCLC patients treated with gefitinib according to the combined status of EGFR FISH and HER3 FISH

\begin{tabular}{|c|c|c|c|c|c|c|c|}
\hline Markers & Total & OR (\%) & SD+PD (\%) & DCR (\%) & PD (\%) & TTP (months) & OS (months) \\
\hline EGFR+and/or HER3+ ${ }^{\mathrm{b}}$ & 39 & $9(23.1)$ & $30(76.9)$ & $20(51.3)$ & $19(48.7)$ & 5.9 & 13.8 \\
\hline $\mathrm{EGFR}-/ \mathrm{HER} 3+^{\mathrm{e}}$ & 11 & 0 & $11(100)$ & $3(27.3)$ & $8(72.7)$ & 2.7 & 7.3 \\
\hline EGFR-/HER3 $-{ }^{f}$ & 43 & $2(4.7)$ & 41 (95.3) & II (25.6) & $32(74.4)$ & 2.6 & 8.5 \\
\hline$P\left({ }^{a} v s^{c}\right)$ & & \multicolumn{2}{|c|}{$\begin{array}{c}\text { I } \\
0.037 *\end{array}$} & \multicolumn{2}{|c|}{1} & 0.32 & 0.85 \\
\hline$P\left(v^{\prime} s^{f}\right)$ & & \multicolumn{2}{|c|}{$0.014 *$} & \multicolumn{2}{|c|}{$0.017 *$} & $0.002 *$ & 0.25 \\
\hline
\end{tabular}

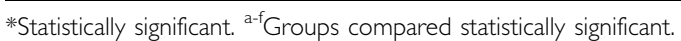
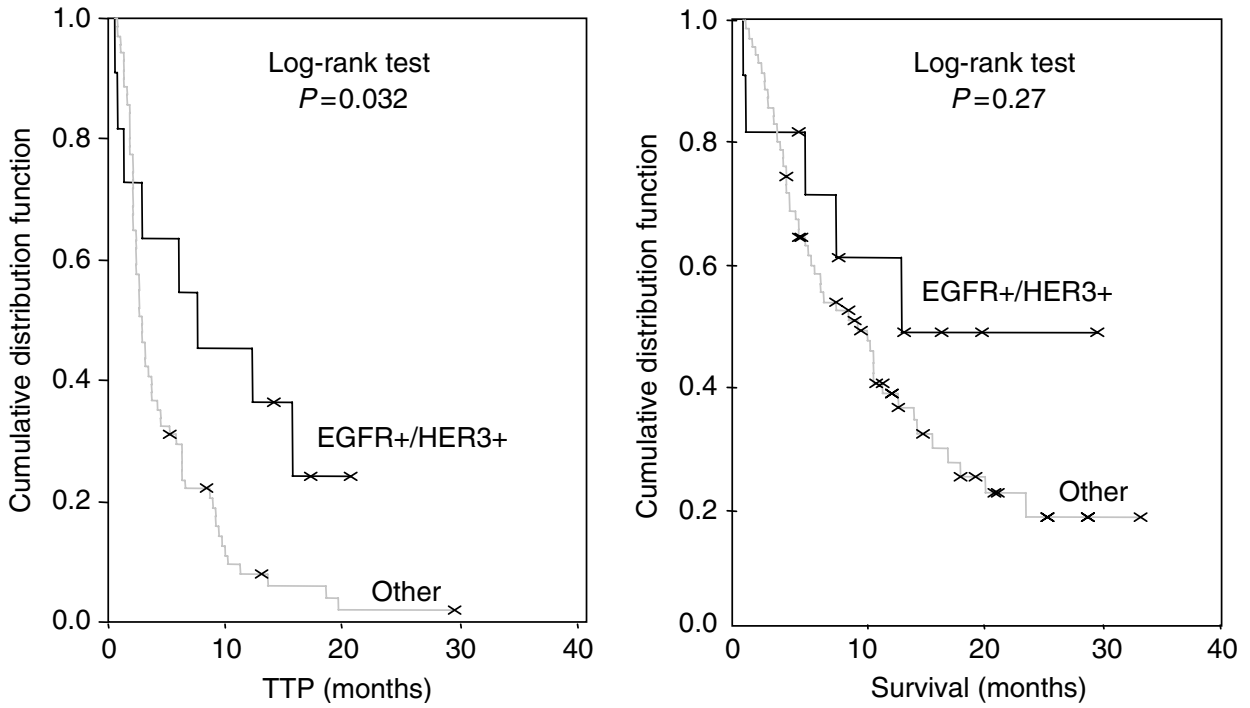

Figure 3 TTP and survival according to HER3/EGFR FISH status. TTP and survival were 7.7 and 13.8 months in EGFR $+/$ HER3 + and 2.7 and I0.I months in patients negative for HER3 and/or EGFR $(P=0.032$ and 0.27 , respectively). 
patients, response rate and survival of patients with increased HER3 gene copy number was not significantly different from the HER3 - patients. The lack of a strong association with gefitinib sensitivity is not surprising because gefitinib is a TKI and HER3 lacks TK activity; thus, it can only signal in the context of a receptor heterodimer. Therefore, the best way to evaluate the impact of HER3 on gefitinib sensitivity is in combination with other EGFR family members, particularly EGFR and HER2.

Combining the EGFR and HER3 gene status determined by FISH, we observed that patients positive for both receptors $($ EGFR $+/$ HER $3+)$ had a significantly higher response and longer TTP, with a nonsignificant trend toward longer survival. Recent data indicate that NSCLCs responding to anti-EGFR therapy are likely to express HER3 at significantly elevated levels (Ono et al, 2004; Engelman et al, 2005). Moreover, preclinical data demonstrate that gefitinib inhibits the growth of HER2 overexpressing cells possibly by sequestration of HER2 and HER3 receptors in an inactive heterodimer configuration with EGFR (Anido et al, 2003). In the present study, although the better outcome was observed among HER3 + /EGFR + patients, the survival advantage was not statistically significant. Importantly, regardless of the method used for EGFR assessment (gene copy number by FISH or mutation analysis by DNA sequencing) no difference was observed among EGFR + patients according to HER3 status. By contrast, our previous analysis conducted in the same cohort of patients demonstrated that HER2 gene increased copy number enhances gefitinib sensitivity in EGFR + patients (Cappuzzo et al, 2005b), with a significant difference in outcome for patients EGFR +1 HER $2+$ and EGFR + /HER2 - . These findings suggest that HER3 is less relevant for gefitinib sensitivity than HER2.

Previous data have shown that the activation of the antiapoptotic PI3K-Akt pathway occurs in patients with mutation in the TK domain of EGFR (Sordella et al, 2004) or gene amplification (Cappuzzo et al, 2005a), and Akt activation results in increased gefitinib sensitivity (Cappuzzo et al, 2004). Because HER3 couples EGFR to the PI3K-Akt pathway in gefitinib-sensitive NSCLC cell lines harboring both wild-type and mutant EGFR (Engelman et al, 2005), we also investigated the correlation of HER3 with P-Akt. Increased HER3 gene copy number was not associated with PAkt + status, and the outcome of patients positive for both HER3 and P-Akt was not significantly different than patients negative for HER3 and/or P-Akt. Although the small number of patients precludes any firm conclusion, it is interesting to note that no response occurred among patients EGFR-/HER3 +/P-Akt + , while a clear benefit was observed among EGFR + /HER3 + /P$\mathrm{Akt}+$ patients. This finding is not surprising because sensitivity to gefitinib is not per se depending on HER3 or P-Akt status, but is related to the presence of the target EGFR, as demonstrated in preclinical (Engelman et al, 2005) and clinical models (Cappuzzo et al, 2005a, b).

Why did this study fail to demonstrate a clinical advantage for HER3 + patients? The major difference with previous studies is that the present report is the first conducted in gefitinib-treated patients and not on cell lines (Anido et al, 2003; Sordella et al, 2004; Engelman et al, 2005). Another important difference is that this investigation was performed at the genomic rather than the protein level. Our previous findings regarding EGFR and HER2 (Cappuzzo et al, 2005a,b) showed that protein expression was positively correlated with genomic status, but FISH results had a higher correlation with clinical outcome than immunohistochemistry results. However, it is conceivable that the same conclusion does not apply for HER3 and epigenetic, posttranscriptional and translational mechanisms could be responsible for an association between higher levels of expression and response to gefitinib. The scarce amount of tumour tissue remaining from our patients has precluded additional analyses to test other hypotheses. Finally, we cannot exclude that the present study was not enough powered to detect a potential benefit for patients with increased copy number of the HER3 gene.

In conclusion, our results suggest that increased copy number of the HER3 gene does not significantly enhance gefitinib sensitivity in EGFR + NSCLC patients, therefore HER3 FISH is not likely to be useful for selection of NSCLC patients for TKI therapy. Further prospective studies in larger cohorts are warranted in order to confirm these findings.

\section{ACKNOWLEDGEMENTS}

We are indebted to the Department of Pathology of the Bellaria Hospital-Bologna, Institute San Raffaele-Milano and Policlinico Monteluce-Perugia for providing patient tissues and clinical data, to AstraZeneca for providing the drug for treatment, and to the Cytogenetics and Tissue Procurement Cores of the University of Colorado Cancer Center for technical assistance. NCI grants Cancer Center Core Grant 2P30-CA46934, Specialised Program of Research Excellence P01-CA58187. FC was a Visiting Professor at the University of Colorado Health Sciences Center sponsored in part by the Department of Medical Oncology of the Bellaria Hospital, Bologna, Italy and in part by the Associazione Italiana Ricerca sul Cancro (AIRC) grant number 2881.

\section{REFERENCES}

Anido J, Matar P, Albanell J, Guzman M, Rojo F, Arribas J, Averbuch S, Baselga J (2003) ZD1839, a specific epidermal growth factor receptor (EGFR) tyrosine kinase inhibitor, induces the formation of inactive EGFR/HER2 and EGFR/ERB-B3 heterodimers and prevents heregulin signaling in HER2-overexpressing breast cancer cells. Clin Cancer Res 9: $1274-1283$

Bell DW, Lynch TJ, Haserlat SM, Harris PL, Okimoto RA, Brannigan BW, Sgroi DC, Muir B, Riemenschneider MJ, Bailey Iacona R, Krebs AD, Johnson DH, Giaccone G, Herbst RS, Manegold C, Fukuoka M, Kris MG, Baselga J, Ochs JS, Haber DA (2005) Epidermal growth factor receptor mutations and gene amplification in non-small-cell lung cancer: molecular analysis of the IDEAL/INTACT gefitinib trials. J Clin Oncol (in press)

Cappuzzo F, Gregorc V, Rossi E, Cancellieri A, Magrini E, Paties CT, Ceresoli G, Lombardo L, Bartolini S, Calandri C, de Rosa M, Villa E, Crino L (2003) Gefitinib in pretreated non-small-cell lung cancer (NSCLC): analysis of efficacy and correlation with HER2 and epidermal growth factor receptor expression in locally advanced or metastatic NSCLC. J Clin Oncol 21: 2658-2663

Cappuzzo F, Hirsch FR, Rossi E, Bartolini S, Ceresoli GL, Ludovini V, Lombardo L, Tonato M, Franklin WA, Crino L, Bunn Jr PA, VarellaGarcia M (2005a) Epidermal growth factor receptor gene and protein and gefitinib sensitivity in non-small cell lung cancer. J Natl Cancer Inst 97: $643-655$

Cappuzzo F, Magrini E, Ceresoli GL, Bartolini S, Rossi E, Ludovini V, Gregorc V, Logorio C, Cancellieri A, Damiani S, Spreafico A, Paties CT, Lombardo L, Calandri C, Bellezza G, Tonato M, Crinò L (2004) AKT phosphorylation and gefitinib efficacy in patients with advanced non-small cell lung cancer. J Natl Cancer Inst 6: $1133-1141$

Cappuzzo F, Varella-Garcia M, Shigematsu H, Domenichini I, Bartolini S, Ceresoli GL, Rossi E, Ludovini V, Gregorc V, Toschi L, Franklin WA, Crinò L, Gazdar AF, Bunn Jr PA, Hirsch F (2005b) Increased HER2 gene copy number is associated with response to gefitinib therapy in epidermal growth factor receptor-positive non-small cell lung cancer patients. J Clin Oncol 23: 5007-5018

Carpenter G, Cohen S (1979) Epidermal growth factor. Annu Rev Biochem 48: $193-216$ 
growth factor receptor underlying responsiveness of non-small-cell lung cancer to gefitinib. N Engl J Med 350: 2129-2139

Chen X, Yeung TK, Wang Z (2000) Enhanced drug resistance in cells coexpressing ErbB2 with EGF receptor or ErbB3. Biochem Biophys Res Commun 277: 757-763

Cho HS, Leahy DJ (2002) Structure of the extracellular region of HER3 reveals an interdomain tether. Science 297: $1330-1333$

Ciardiello F, De Vita F, Orditura M, De Placido S, Tortora G (2003) Epidermal growth factor receptor tyrosine kinase inhibitors in late stage clinical trials. Expert Opin Emerg Drugs 8: 501-514

Eberhard DA, Johnson BE, Amler LC, Goddard AD, Heldens SL, Herbst RS, Ince WL, Janne PA, Januario T, Johnson DH, Klein P, Miller VA, Ostland MA, Ramies DA, Sebisanovic D, Stinson JA, Zhang YR, Seshagiri S, Hillan KJ (2005) Mutations in the epidermal growth factor receptor and in KRAS are predictive and prognostic indicators in patients with nonsmall-cell lung cancer treated with chemotherapy alone and in combination with erlotinib. J Clin Oncol 23: 5900-5909

Engelman JA, Janne PA, Mermel C, Pearlberg J, Mukohara T, Fleet C, Cichowski K, Johnson BE, Cantley LC (2005) ErbB-3 mediates phosphoinositide 3-kinase activity in gefitinib-sensitive non-small cell lung cancer cell lines. Proc Natl Acad Sci USA 102: 3788-3793

Fedi P, Pierce JH, di Fiore PP, Kraus MH (1994) Efficient coupling with phosphatidylinositol 3-kinase, but not phospholipase $\mathrm{C}$ gamma or GTPase-activating protein, distinguishes ErbB-3 signaling from that of other ErbB/EGFR family members. Mol Cell Biol 14: 492-500

Fukuoka M, Yano S, Giaccone G, Tamura T, Nakagawa K, Douillard JY, Nishiwaki Y, Vansteenkiste J, Kudoh S, Rischin D, Eek R, Horai T, Noda K, Takata I, Smit E, Averbuch S, Macleod A, Feyereislova A, Dong RP, Baselga J (2003) Multi-institutional randomized phase II trial of gefitinib for previously treated patients with advanced non-small-cell lung cancer. J Clin Oncol 21: 2237-2246

Greenlee RT, Hill-Harmon MB, Murray T, Thun M (2001) Cancer statistics 2001. CA Cancer J Clin 51: 15-36

Guy PM, Platko JV, Cantley LC, Cerione RA, Carraway III KL (1994) Insect cell-expressed p180erbB3 possesses an impaired tyrosine kinase activity. Proc Natl Acad Sci USA 91: 8132-8136

Hirsch FR, Varella-Garcia M, McCoy J, West H, Xavier AC, Gumerlock P, Bunn Jr PA, Franklin WA, Crowley J, Gandara DR, Southwest Oncology Group (2005) Increased epidermal growth factor receptor gene copy number detected by fluorscence in situ hybridization associates with increased sensitivity to gefitinib in patients with bronchioloalveolar carcinoma subtypes: a Southwest Oncology Group Study. J Clin Oncol 23: $6838-6845$

Kaplan EL, Meier P (1985) Nonparametric estimation from incomplete observations. J Am Stat Assoc 53: 457-481

Kelly K, Crowley J, Bunn Jr PA, Presant CA, Grevstad PK, Moinpour CM Ramsey SD, Wozniak AJ, Weiss GR, Moore DF, Israel VK, Livingston RB, Gandara DR (2001) Randomized phase III trial of paclitaxel plus carboplatin $v s$ vinorelbine plus cisplatin in the treatment of patients with advanced non - small-cell lung cancer: a Southwest Oncology Group trial. J Clin Oncol 19: 3210-3218

Krahn G, Leiter U, Kaskel P, Udart M, Utikal J, Bezold G, Peter RU (2001) Coexpression patterns of EGFR, HER2, HER3 and HER4 in nonmelanoma skin cancer. Eur J Cancer 37: 251-259

Kris MG, Natale RB, Herbst RS, Lynch Jr TJ, Prager D, Belani CP, Schiller JH, Kelly K, Spiridonidis H, Sandler A, Albain KS, Cella D, Wolf MK, Averbuch SD, Ochs JJ, Kay AC (2003) Efficacy of gefitinib, an inhibitor of the epidermal growth factor receptor tyrosine kinase, in symptomatic patients with non-small cell lung cancer: a randomized trial. JAMA 290: $2149-2158$

Landgraf R, Eisenberg D (2000) Heregulin reverses the oligomerization of HER3. Biochemistry 2000; 39: 8503-8511

Lynch TJ, Bell DW, Sordella R, Gurubhagavatula S, Okimoto RA, Brannigan BW, Harris PL, Haserlat SM, Supko JG, Haluska FG, Louis DN, Christiani DC, Settleman J, Haber DA (2004) Activating mutations in the epidermal
Naidu R, Yadav M, Nair S, Kutty MK (1998) Expression of c-erbB3 protein in primary breast carcinomas. Br J Cancer 78: $1385-1390$

Non-small cell Lung Cancer Collaborative Group (1995) Chemotherapy in non-small cell lung cancer: a meta-analysis using updated data on individual patients from 52 randomized clinical trials. $B M J 311$ $899-909$

Ono M, Hirata A, Kometani T, Miyagawa M, Ueda S, Kinoshita H, Fujii T, Kuwano M 2004 Sensitivity to gefitinib (Iressa, ZD1839) in non-small cell lung cancer cell lines correlates with dependence on the epidermal growth factor (EGF) receptor/extracellular signal-regulated kinase 1/2 and EGF receptor/Akt pathway for proliferation. Mol Cancer Ther 3: $465-472$

Paez JG, Janne PA, Lee JC, Tracy S, Greulich H, Gabriel S, Herman P, Kaye FJ, Lindeman N, Boggon TJ, Naoki K, Sasaki H, Fujii Y, Eck MJ, Sellers WR, Johnson BE, Meyerson M (2004) EGFR mutations in lung cancer: correlation with clinical response to gefitinib therapy. Science 304: $1497-1500$

Pao W, Miller V, Zakowski M, Doherty J, Politi K, Sarkaria I, Singh B, Heelan R, Rusch V, Fulton L, Mardis E, Kupfer D, Wilson R, Kris M, Varmus H (2004) EGF receptor gene mutations are common in lung cancers from 'never smokers' and are associated with sensitivity of tumors to gefitinib and erlotinib. Proc Natl Acad Sci USA 101: $13306-$ 13311

Schiller JH, Harrington D, Belani CP, Langer C, Sandler A, Krook J, Zhu J, Johnson DH, Eastern Cooperative Oncology Group (2002) Comparison of four chemotherapy regimens for advanced non-small-cell lung cancer. $N$ Engl J Med 346: 92 - 98

Shepherd FA, Rodrigues Pereira J, Ciuleanu T, Tan EH, Hirsh V, Thongprasert S, Campos D, Maoleekoonpiroj S, Smylie M, Martins R, van Kooten M, Dediu M, Findlay B, Tu D, Johnston D, Bezjak A, Clark G, Santabarbara P, Seymour L (2005) Erlotinib in previously treated nonsmall-cell lung cancer. N Engl J Med 353: 123-132

Sliwkowski MX, Schaefer G, Akita RW, Lofgren JA, Fitzpatrick VD, Nuijens A, Fendly BM, Cerione RA, Vandlen RL, Carraway III KL (1994) Coexpression of erbB2 and erbB3 proteins reconstitutes a high affinity receptor for heregulin. J Biol Chem 269: 14661-14665

Sordella R, Bell DW, Haber DA, Settleman J (2004) Gefitinib-sensitizing EGFR mutations in lung cancer activate anti-apoptotic pathways. Science 305: $1163-1167$

Thatcher N, Chang A, Parikh P, Pemberton K, Archer V (2005) ISEL: a Phase III survival study comparing gefitinib (IRESSA) plus best supportive care (BSC) with placebo plus BSC, in patients with advanced non-small-cell lung cancer (NSCLC) who had received one or two prior chemotherapy regimens. Lung Cancer 49(Suppl 2): s4 (abstract)

Therasse P, Arbuck SG, Eisenhauer EA, Wanders J, Kaplan RS, Rubinstein L, Verweij J, Van Glabbeke M, van Oosterom AT, Christian MC, Gwyther SG (2000) New guidelines to evaluate the response to treatment in solid tumors. European Organization for Research and Treatment of Cancer, National Cancer Institute of the United States, National Cancer Institute of Canada. J Natl Cancer Inst 92: 205-216

Travis WD, Colby TV, Corrin B (1999) Histological Typing of Lung and Pleural Tumors, 3rd edn. Berlin: Springer

Tsao MS, Sakurada A, Cutz JC, Zhu CQ, Kamel-Reid S, Squire J, Lorimer I, Zhang T, Liu N, Daneshmand M, Marrano P, da Cunha Santos G, Lagarde A, Richardson F, Seymour L, Whitehead M, Ding K, Pater J, Shepherd FA (2005) Erlotinib in lung cancer - molecular and clinical predictors of outcome. $N$ Engl J Med 353: 133 - 144

Woodburn JR (1999) The epidermal growth factor receptor and its inhibition in cancer therapy. Pharmacol Ther 82: 241-250

Yarden Y, Ullrich A (1988) Growth factor receptor tyrosine kinases. Annu Rev Biochem 57: $443-478$ 